\title{
Hybrid Resistance Units
}

National Cancer Institute

\section{Source}

National Cancer Institute. Hybrid Resistance Units. NCI Thesaurus. Code C150900.

A unit of resistance equal to the number of millimeters of mercury times minutes, per unit of volume equal to one liter. 